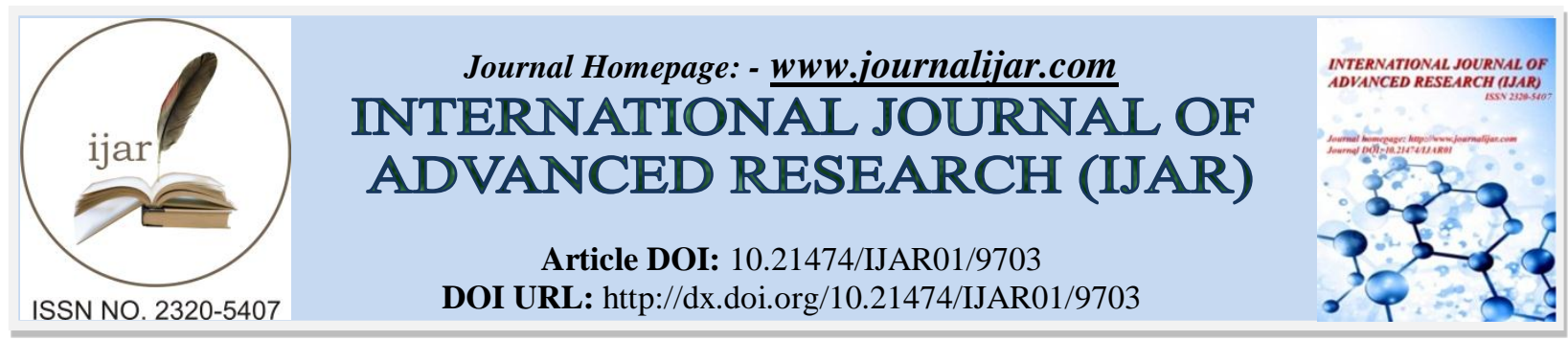

RESEARCH ARTICLE

\title{
NYAGRODHA:AN INSIGHT TOWARDS AYURVEDIC PHARMACOLOGY.
}

Aswathy Viswan ${ }^{1}$ and Dr.Shincymol.V.V ${ }^{2}$.

1. Final year PG Scholar, Dept. of Dravyaguna Vijnana, Govt. Ayurveda College, Thripunithura, Kerala, India.

2. Associate Professor, Dept. of Dravyaguna Vijnana, Govt. Ayurveda College, Thripunithura, Kerala, India.

\section{Manuscript Info}

Manuscript History

Received: 08 July 2019

Final Accepted: 10 August 2019

Published: September 2019

Key words:-

Nyagrodha,Panchavalkala,Ksheerivrksha

,Therapeutic properties.

\begin{abstract}
Nyagrodha(Ficus bengalensis Linn) also called Vata in Ayurveda is an important ingredient of many Ayurvedic formulations.It belongs to the category of Pancha ksheerivrksha in Ayurveda.Nyagrodha posses many useful parts which have medicinal value such as stem bark,aerial roots,leaves,latex etc.The stem bark of Nyagrodha ,which is one among Panchavalkala is also having wide range of uses in Ayurveda. Panchavalkala is the group of stem bark of five medicinal species in Ayurvedic system of medicine, which is an ingredient of many formulations.As per reference of Sharangadhara samhitha if drug Nyagrodha is mentioned,the stem bark should be used .Being stem bark as most useul part, each part of Nyagrodha posses different medicinal properties in Ayurvedic classics. Nyagrodha is an ingredient of many Ayurvedic formulations such as ,Panchavalkala kasaya,Chandanasavam, Useerasava,Arimedadi taila,Nalpamaradi kera etc.On analysing the treatise, it is found that the drug is generally kapha-pitha-rakthahara in nature and is mainly indicated in rakthapitha,vrana etc,but its properties varies as per the parts used.Many properties of Nyagrodha are not widely explored yet, thus here is an attempt to describe various parts of Nyagrodha in detail owing to its therapeutic properties.
\end{abstract}

Copy Right, IJAR, 2019,. All rights reserved.

\section{Introduction:-}

Nyagrodha (Ficus bengalensis Linn) is a sacred medicinal plant since Vedic times. The drug is having many vedic references but its medicinal uses are well explored in later samhithas and nighantus.In samhithas and nighantus elaborative descriptions of medicinal uses of Nyagrodha are available.Other than being ingredient of various formulations many single drug remedies with various parts of Nyagrodha are available in Ayurvedic literature.This can be traced by detail understanding of references in Ayurvedic literature as follows.

Nirukthi (Etymology):

The word Nyagrodha is derived from root 'rudh aavarane' which means that which cause obstruction on the way by sending aerial roots down.

\section{न्यग्रोध:-“न्यक्र रुणदि इति",1}

Corresponding Author:-Aswathy Viswan.

Address:-Final year PG Scholar, Dept. of Dravyaguna Vijnana, Govt. Ayurveda College, Thripunithura, Kerala India 
It is also called Vata, which has derivation from the root 'vata veshtane'. It implies that which winds around using support.

\section{वट:-“वटति वेष्टते आवृणोतीति",}

Classification of Nyagrodha

Table No1.1:-Classification of Nyagrodha according to Samhita / Samgraha

\begin{tabular}{|l|l|l|}
\hline Sl no: & Text & Varga / Gana \\
\hline $\mathbf{1}$ & Charaka Samhita & Muthrasangrahaneeya $^{3}$ \\
\hline $\mathbf{2}$ & Susrutha Samhita & Nyagrodadi gana $^{4}$ \\
\hline $\mathbf{3}$ & Ashtanga Hridaya & $\begin{array}{l}\text { Nyagrodadi gana } \\
\text { Pittagna gana }\end{array}$ \\
\hline
\end{tabular}

Table No1.2:-Classification of Nyagrodha according to Nighantus

\begin{tabular}{|c|c|c|}
\hline Sl no: & Nighantu & Varga/Gana \\
\hline 1 & Ashtanga Nighantu & $\begin{array}{l}\text { Nyagrodhadi gana } \\
\text { Pittagna gana }\end{array}$ \\
\hline 2 & Dhanvantari nighantu & Amradi varga ${ }^{8}$ \\
\hline 3 & Sodhala nighantu & Amradi varga ${ }^{9}$ \\
\hline 4 & Madanapala nighantu & $\begin{array}{l}\text { Vatadi varga } \\
\text { Panchavalkalam }\end{array}$ \\
\hline 5 & Raja nighantu & Amradi varga ${ }^{11}$ \\
\hline 6 & Kaiyadeva nighantu & $\begin{array}{l}\text { Oushadi varga }^{12} \\
\text { Panchavalkalam }\end{array}$ \\
\hline 7 & Bhavaprakasa nighantu & $\begin{array}{l}\text { Vatadi varga } \\
\text { Pancha ksheerivrksha }^{13} \\
\text { Panchavalkala }^{13}\end{array}$ \\
\hline 8 & Saligrama nighantu & Vatadi varga ${ }^{15}$ \\
\hline 9 & Priya nighantu & Harithakyadi varga $^{16}$ \\
\hline 10 & Nighantu adarsha & Vatadi varga $^{15}$ \\
\hline
\end{tabular}

Rasapanchaka and Doshakarma of Nyagrodha

Most of nighantus mention rasa of Nyagrodha as kashaya but in raja nighantu additional madura rasa is mentioned along with kashaya rasa. In case of guna, seetha, ruksha, guru are frequently mentioned. Veerya is mentioned as seetha in all nighantus and A.P.I .Vipaka is mentioned as katu in A.P.I. Regarding the doshakarma, Nyagrodha is mentioned as kapha-pithahara by most nighantus.

\begin{tabular}{|c|c|c|c|c|c|}
\hline Nighantu & Rasa & Guna & Veerya & Vipaka & Doshakarma \\
\hline D.N & Kashaya & $\begin{array}{l}\text { Seetha } \\
\text { Ruksha }\end{array}$ & Seetha & & $\begin{array}{l}\text { Raktha- } \\
\text { Pithahara }\end{array}$ \\
\hline MPN & & $\begin{array}{l}\text { Guru } \\
\text { Seetha }\end{array}$ & Seetha & & $\begin{array}{l}\text { Kapha- } \\
\text { pithahara }\end{array}$ \\
\hline RN & $\begin{array}{l}\text { Kashaya, } \\
\text { Madura }\end{array}$ & Seetha & Seetha & & $\begin{array}{l}\text { Kapha- } \\
\text { pithahara }\end{array}$ \\
\hline KN & Kashaya & $\begin{array}{l}\text { Guru } \\
\text { Ruksha } \\
\text { Seetha }\end{array}$ & Seetha & & $\begin{array}{l}\text { Kapha- } \\
\text { pithahara }\end{array}$ \\
\hline BPN & Kashaya & $\begin{array}{l}\text { Seetha } \\
\text { Guru }\end{array}$ & Seetha & & $\begin{array}{l}\text { Kapha- } \\
\text { pithahara }\end{array}$ \\
\hline A.O.N ${ }^{19}$ & Kashaya & Guru & Seetha & & \\
\hline A.P. $\mathbf{I}^{20}$ & Kashaya & Guru & Seetha & Katu & \\
\hline
\end{tabular}


\begin{tabular}{|l|l|l|l|l|}
\hline & Ruksha & & & \\
\hline
\end{tabular}

Table No 1.3:-Rasa, Guna, Virya, Vipaka, and Doshakarma of Nyagrodha twak

Karmukta of Nyagrodha

On analyzing the karma of Nyagrodha, the dug posses grahi, sthambhana, varnya and rookshana properties.

Table No 1.4:-Karmukta of Nyagrodha according to various classics

\begin{tabular}{|l|c|c|c|c|c|c|}
\hline Karmukta & D.N & So.N & M.P.N & R.N & K.N & B.P.N \\
\hline Grahi & & & + & & + & + \\
\hline Varnya & & & & & + & + \\
\hline Sthambhana & + & & & & & \\
\hline Rookshanathmaka & + & & & & & \\
\hline
\end{tabular}

\section{Therapeutic indications of Nyagrodha (rogaghnata)}

The knowledge of rasapanchaka of a drug is vital in utilizing it in treatment for rogas. Rasapanchaka of the drug ascertain its specific usage in rogas depending upon the srothas and samsthana involved. On analyzing the rogas, it can be inferred that the Nyagrodha is mostly indicated in kapha-pitha disorders like daha, trshna, moha etc.

Table No 1.5:-Therapeutic indications of Nyagrodha

\begin{tabular}{|c|c|c|c|c|c|}
\hline & D.N & M.P.N & R.N & K.N & B.P.N \\
\hline Chardi & + & & & & \\
\hline Daha & & & + & & + \\
\hline Jwara & & & + & & \\
\hline Moha & & & + & & \\
\hline Moorcha & + & & & & \\
\hline Raktapitha & + & & & & \\
\hline Sopha & & & + & & \\
\hline Trshna & + & & + & & \\
\hline Visarpa & & & & + & + \\
\hline Vrana & & + & + & + & + \\
\hline Yonidosha & & & & + & + \\
\hline
\end{tabular}

\section{Properties of different parts of Nyagrodha}

Different parts of Nyagrodha possess different rasapanchaka and karmas. These properties were not described in the samhita period but later in the nighantu kala; various nighantus have mentioned individually properties of different parts of Nyagrodha.

\section{Properties of Nyagrodha Patra:}

Properties of ksheerivrksha patra which includes nyagrodhapatra is explained in madanapala nighantu, kaiyadeva nighantu and bhavaprakasa nighantu as follows.

Table No 1. 6:-Properties of Nyagrodha patra

\begin{tabular}{|l|l|l|l|}
\hline & M.P.N & K.N & B.P.N $^{19}$ \\
\hline Rasa & & Madura, Tiktha, Kasaya & Kasaya \\
\hline Guna & Laghu & Laghu & Laghu \\
\hline Veerya & Seetha & Seetha & Seetha \\
\hline Doshakarma & Kaphavatasranuth & Tridoshahara & Kaphavatasranuth \\
\hline Karmukatha & Samgrahi & Lekhana & Lekhana \\
\hline
\end{tabular}

\section{Properties of Nyagrodhapallava ${ }^{18}$ :}

Properties of ksheerivrkshapallava which includes nyagrodhapallava is explained in kaiyadeva nighantu as kashaya rasa, seethaguna, sthambhaka and is beneficial in pithathisara. 


\section{Properties of Nyagrodha Phala:}

Properties of ksheerivrksha phala which includes nyagrodha phala is explained in sodhala nighantu, kaiyadeva nighantu, madanapala nighantu as follows.

Table No 1.7:-Properties of Nyagrodhaphala

\begin{tabular}{|l|l|l|l|}
\hline & So.N & K.P.N $^{11}$ \\
\hline Rasa & $\begin{array}{l}\text { Kashaya, Madura, } \\
\text { Amla }\end{array}$ & $\begin{array}{l}\text { Kashaya, Madura, } \\
\text { Amla }\end{array}$ & \\
\hline Guna & Guru, Rooksha & Guru & \\
\hline Veerya & Seetha & & Raktha-Pitha-Kaphahara \\
\hline Doshakarma & $\begin{array}{l}\text { Kaphapithahara } \\
\text { Vatakopana }\end{array}$ & Vatakrth, Pithajith & Vishtambhi, Samgrahi \\
\hline Karmukatha & Sthambana, Lekhana & & \\
\hline
\end{tabular}

\section{Properties of Nyagrodha ksheeram ${ }^{18}$ :}

In kaiyadeva nighantu, ksheera of ksheerivrksha is attributed with qualities such as ushna, guru, snigdha, kaphavatahara, pithakrth and is beneficial in vatagulma, hrllasa, aruchi, sopha etc.

Properties of Nyagrodha jata ${ }^{20}$ :

In API ,properties of aerial roots of Nyagrodha is explained.

Table No 1.8:-Properties of Nyagrodha jata

\begin{tabular}{|l|l|}
\hline & API \\
\hline Rasa & Madura, Kashaya \\
\hline Vuna & Guru, Ruksha \\
\hline Vipaka & Seetha \\
\hline Doshahara & Madura \\
\hline Karmas & Kapha-Pithahara \\
\hline Therapeutic indications & $\begin{array}{l}\text { Grahi, Sthambhaka, Varnya, } \\
\text { Bhagnasandhanakara, Ropana, Kesya }\end{array}$ \\
\hline & $\begin{array}{l}\text { Daha, Visarpa, Rakthapitha, Trshna, } \\
\text { Yoniroga, Medoroga, Bhagandara }\end{array}$ \\
\hline
\end{tabular}

\section{Properties of Panchavalkala:}

In bhavaprakasa nighantu and madanapala nighantu, panchavalkala includes stem bark of nyagrodha, udumbara, aswadha, parisha and plaksha. The properties of panchavalkala mentioned are same such as hima, grahi, vranasopha visarpajith.

\section{Properties of Panchaksheerivrksha:}

In bhavaprakasa nighantu and madanapalanighantu, the tree comes under panchavalkala dravya is again grouped under panchaksheerivrksha ie., trees having milky latex. The properties of ksheerivrksha enlisted in madanapalanighantu are hima ,kaphapithahara, yonidoshavranapaha, sthanya ,bhagnasthiyogada. In bhavaprakasa nighantu, ksheerivrksha is attributed with properties such as kashaya rasa, hima, ruksha, medoghna and is beneficial in visarpa, yoniroga, vrana etc.

\section{Ksheerivrksha ${ }^{21}$ :}

Rasa tharangani grouped ksheera of arka, vata and snuhi together as ksheerathrayam and the milky latex are used in the process of marana.

\section{Formulations of Nyagrodha}

Table No 1.9:-Formulations of Nyagrodha

\begin{tabular}{|l|l|l|}
\hline Formulations & Roga & References \\
\hline Choorna & & \\
\hline Nalpamaradi choorna & Pipasa & Sahasrayoga \\
\hline Kashayam & \\
\hline
\end{tabular}




\begin{tabular}{|l|l|l|}
\hline Nyagrodhadi kasaya & Yoniroga & Sha.Sa.Madyamakhanda \\
\hline Panchavalkala kasaya & Vrana & Sha. Sa. Madyamakhanda \\
\hline Amradiphanta kasaya & Jwara etc & Sha. Sa. Madyamakhanda \\
\hline \multicolumn{2}{|l|}{ Pudapaka } & Athisara \\
\hline Tithiri pudapaka & Sha. Sa. Madyamakhanda \\
\hline Asava & Rakthapitha, Pandu etc & Sahasrayoga \\
\hline Usirasava & Suklameha & Sahasrayoga \\
\hline Chandanasava & $\begin{array}{l}\text { Prameha, Prameha } \\
\text { pidaka,Upadamsa }\end{array}$ & Sahasrayoga \\
\hline Saribadyasava & Mukharoga & \\
\hline Snehayogas & Visarpa,Kushta etc & Sahasrayoga \\
\hline Arimedadi taila & Sahasrayoga \\
\hline Nalpamaradi kera & Kushta & Sahasrayoga \\
\hline Kachoradi choorna & Vyanga & Ashtanga hridaya (Kshudraroga chikitsa) \\
\hline Kumkumadi taila & Netraroga & Sahasrayoga \\
\hline Gudikas & Trshna & Sha. Sa. Madyamakhanda \\
\hline Mukkadipurampada &
\end{tabular}

\section{Conclusion:-}

Thus it is understood that the drug Nyagrodha is having wide range of therapeutic potential,due to its multiple useful parts,such as stem bark, latex,leaf bud,leaves etc as per descriptions available so far.

\section{Acknowledgement:-}

I express my immense respect and gratitude towards the Dr.P.Y Ansary; HOD of the department of Dravyagunavijnana, Govt. Ayurveda College, Thripunithura, for his motivation for doing this work. I am thankful to my guide Dr. Shincy mol V.V,Associate Professor, department of Dravyagunavijnana, Govt. Ayurveda College, Thripunithura, for her meticulous guidance and support for the completion of entire work.

\section{References:-}

1. Raja Radha Kanta Deva. Editor, Sabdakalpadrumam, Varanasi, Chaukambha Sanskrit Series, Vol.2, p:626

2. Raja Radha Kanta Deva. Editor, Sabdakalpadrumam, Varanasi, Chaukambha Sanskrit Series, Vol.5, p:252

3. Vaidya YadavajiTrikamji, Editor, CharakaSamhitha of Agnivesha with Ayurveda Dipika commentary by Chakrapani; Sootrasthana, Choukhambha Sanskrit Prasthan, Page no:33,ver 33

4. Vaidya YadavajiTrikamji, Editor, Susruthasamhitha of Susrutha with Nibadhasamgraha commentary of Dalhana, Sootrasthana, 2010, Ch 38, Ver 67, Choukhambha Sanskrit Samsthan, Page no 169

5. HariSadasivaSastriParadakara, AshtangaHridaya of Vagbhata with Sarvangasundari commentary of Aruna data and Ayurveda rasayana commentary of Hemadri,Sootrasthana,Chapter 15,Ver 41,6,Choukhambha Sanskrit samsthan ,Varanasi, 2010

6. Murthy Srikantha K.R, Sarangadharasamhita by Sarangadhara, Reprint Edition, Prathamakhanda, Ch. 1 Ver: 61, Varanasi, Chowkhambhaorientalia, 2009, Pg no:9

7. http://niimh.nic.in/ebooks/e Nighantu/ashtanganighantu

8. Dr.S.D Kamath,Studies on medicinal plants and drugs in Dhanwanthari Nighantu 1 edition 2002 Delhi,Choukamba Sanskrit Prasthan page no:426

9. R R Dwiwedi. Editor, Acharya Shodhala's Shodhala Nighantu, 1st edition, 2009, Varanasi, Choukambha Krishnadas Academy, p.285

10. Dr J.L.N Sastry.Illustrated Madanapala Nighantu.I edition 2010,Varanasi,Choukamba Orientalia.Page no:491 
11. Tripathi Indradeva. Editor, Raja Nighantu of Pandit Raja Narahari, Varanasi, Choukambha Krishnadas Academy, p:363,364

12. Sharma P V. \& Sharma Guru Prasad, Editor \& Translator, Kaiyadeva Nighantu,I edition 1979, Varanasi, Choukambha Orientalia, page no:78

13. Dr.G.S Pandey Editor ,Bhavaprakasanighantu,Commentory by Dr.K.C Chunekhar,Choukambaha Bharathi Academy,Page no:514

14. e-nighantu. Delhi, CCRAS,2012-03-24, 2018-06-18, http://niimh.nic.in/ebooks/eNighantu/abhidhana ratnamala

15. Sri Baplal Vaidya,Nighantu Adarsha Uttarasthanam.Reprint 2005 Varanasi,Choukamba Bharathi Academy page no:470

16. Sharma P V., Editor \& Translator, Priya Nighantu, Edition 2004, Varanasi,Choukambha Subharathi Granthamala , p:25

17. Dr J.L.N Sastry.Illustrated Madanapala Nighantu.I edition 2010,Varanasi,Choukamba Orientalia.Page no:498

18. Sharma P V. \& Sharma Guru Prasad, Editor \& Translator, Kaiyadeva Nighantu,I edition 1979, Varanasi, Choukambha Orientalia, page no:81

19. Dr.G.S PandeyEditor ,Bhavaprakasanighantu,Commentory by Dr.K.C Chunekhar,Choukambaha Bharathi Academy,Page no:519,520

20. Ayurveda Pharmacopoeia of India, $1^{\text {st }}$ edition, Part $1, \mathrm{Vol}$ 1,GOI,Ministry of Health and Family welfare, Page no:, 118

21. Pandit KasinadhSastri,Rasatharangani,Mothilal banarasidas publications,Page no:15 vers:157. 